\title{
Implementation Interactive Media and Characterized Meme Media: A Comparation Study
}

\author{
Adi Sumarsono ${ }^{1}$, Murni Sianturi² \\ ${ }^{1}$ Department of Physical Education, Health and Recreation, Faculty of Teacher Training and Education, \\ Musamus University, Indonesia \\ ${ }^{2}$ Department of Mathematics Education, Faculty of Teacher Training and Education, Musamus University, \\ Indonesia \\ adi@unmus.ac.id,murni@unmus.ac.id
}

\begin{abstract}
This study aimed to determine the effectiveness of the implementation of interactive media and characterized meme media on the student learning. This study applied experimental research method which used simple random sampling technique. The participants of the study consisted of two group as group A amount twenty-nine students and group B amount twenty-eight students. Each group had a different treatment, for the group a was treated by implementing interactive media, while group B was treated by implementing characterized memes media. Data analysis applied hypothesis testing of paired sample t-test and obtained that both of implementing of interactive media, and implementing characterized memes media, probability value .00 was less than alpha value, .05 , which means the media provide impact to the student learning. Data analysis applied hypothesis testing of independent sample t-test and obtained p, .972 was greater than alpha value, .05. Thus, there was no difference between student learning achievement taught by using interactive media and characterized memes media. However, in accordance with effective criteria, it was presented that interactive learning media is more effective than characterized memes media. The percentage of classical completeness of students who were taught by using interactive learning media enhanced to 89.12 percent, while using characterize memes learning media reach 60.41 that not reached the classical completeness. In addition, in terms of appropriate student learning activity in the classroom using interactive media reached 90.12 percent, while in memes characterized media class character merely 66.65 percent.
\end{abstract}

Keywords: Effectiveness, interactive media, characterized memes media.

\section{Introduction}

As a subject related to physical activity, the physical subject is not merely concern to what student activity is performing. However, the behavior of physical activity in the past is a precursor of the behavior of physical activity in the future. The participation of physical activity in the youth forms a prerequisite for future physical activity in the future (Smith et al., 2015). By using the opened book, confirmed that problem comprehensive skill student was getting lower (Roux et al., 2018). Thus, it should be taught in various techniques. Teachers should improve their instructional designs (Sumarsono, 2017) and consider the students' needs, characteristic (Sianturi \& Lin, 2017) and physical growth (Sumarsono, 2018). Particularly in the elementary level, the monotone learning stirred to decline the student motivation and involvement student in the learning process (Sun, 2013). A decade or more of experimentation resulted in the understanding that each style of teaching was not inherently better or more effective than the others, but rather that each style met a specific set of unique objectives or goals (Sianturi, Chiang \& Hurit, 2018). For example, in the reciprocal style immediate feedback and cooperative behavior are the essences of the style and learners are given an opportunity to practice a given task under the direct observation of a peer. Takabayashi (2017) stated it is necessary how to encourage self-directed media use.

The more we know about effective uses of technologies for teaching and learning, the faster we can adopt these new practices, facilitate their proliferation across higher education, and increase student success (Seaman, 2013). The success of students has traditionally been influenced by assignments, activities and assessments in class, but one of the supporters of success that is often overlooked is the role of the media (Conrad, 2017). Current curriculum in Indonesia considered to extend the allocation of teaching hour of the physical subject. For elementary, it becomes four hours per week, meanwhile for junior high it becomes three per hour. Although, previously it was only two hour. With this extension, means it needs to keep the student's concentration while the students are learning. Instead of the teacher teaches students by giving the material in conventional ways, it is necessary to apply meaningful ways. Therefore, this study considered to apply interactive media and characterized memes media in the classroom to investigate whether student learning 
could be improved. This research was important because the characteristics of the two media are similar which is both used visual media with computer assistance.

\section{Literature Review}

To bridge the process of learning a teacher must be able to create and select the media as a tool in delivering the material. Kariman (2014) stated instructional media as channelling or messenger tools to deliver unlimited instructional issues or other types of teaching and learning activities. Even a simple tool as long as its functions as a messenger and information from one person to another could be considered as media. Daryanto (2010) defined learning media as tools and materials used in learning activities. Instructional media provide benefit to the teacher as well as a student in teaching and learning process. Instructional media present lessons to be more concrete in order to facilitate students to comprehend them. According to Arsyad (2011: 36), the instructional media is divided into five groups such as: human-based media (teachers, instructors, tutors, role play, group activities), printed, visual-based media (books, work aids, charts, graphics, maps, slide transparency images), audio-visual based media (video, film, tape slide programs, television and computer-based media (computer, interactive, video and hypertext).

The selection of the instructional media is adjusted to learning objectives. Interactive media is a medium created in order to build interaction between two or more objects so that has an effect on each other. Meme characterized media is still not popular among teachers and educators. This media actually already exist in the middle of society with spreading the use of social media. This media included as one of ICT (Information Communication Technology). The meaning of the word meme was introduced by a biologist named Richard Dawkins in 1976 which is famous in his book entitled "the selfish gene" in his book Dawkins mentioned: "we need a name for the new replicator, a noun that conveys the idea of a unit of imitation: mimeme" comes from a suitable Greek root, nut i want a monosyllable that sound a bit like "gene". I hope my classicist friends will forgive me if I abbreviate mimeme to the meme". The meaning of characterized memes media is a picture along with words in order to support the expression of the image. The words could be funny or inspiration words. Eventually, the words are adjusted to the level of the students and learning topics.

\section{Research Methods}

This study applied a quasi-experiment research method. The experimental research design used in this research is the pretest experimental posttest control group design. In this research there were two classes studied with different treatment. Research design in this research as follows:

Table 1: Research Design

\begin{tabular}{llll}
\hline Group & Pretest & Treatment & Posttest \\
\hline I & 01 & $M_{1}$ & 02 \\
II & 01 & $M_{2}$ & 02 \\
\hline
\end{tabular}

$\mathrm{M}_{1}=$ Interactive Media

$\mathrm{M}_{2}=$ Characterized Memes Media

The study took place at Junior High School Buti Merauke, in particular at seventh grade which consists of four parallel class amount 116 students. Sample selection in this study using a random sampling technique. The participants of the study consisted of two groups as group an amount twenty-nine students and group B amount twenty eight students. Each group had a different treatment, for the group a was treated by implementing interactive media, while group B was treated by implementing characterized memes media. Independent variable was instructional media, while the dependent variable was the effectiveness of instructional media of student activity and student learning achievement. To gather the data in this study using two kinds of instruments that were test and student activity sheet. The test referred to healthy lifestyle topic. There are fifteen items, including ten multiple choices and five essays. The student's activities were observed by using student activity sheet. There are sixteen items, consists of five domains which are visual, oral, listening, writing, motor activity. According to effective learning is learning which accomplish the learning objectives. Therefore, in this study the criteria of effective learning including: 1) classical learning completeness, 2) achievement of teaching effectiveness in the learning process, 3) achievement of student's 
learning effectiveness dealing with teaching hour contained in the lesson plan. The effectiveness was measured from enhancing of student learning achievement, classical completeness, teaching and student learning activity at least in the effective enough category. The classical completeness means when eighty five percent students achieve score seventy five. Test was analyzed statistically using parametric statistics with t-test with alpha level 0.05 .

The type of t-test used in this research is paired sample t-test and independent sample t-test. Data from student activity sheet was analyzed and described by referring to the interval of effectiveness criteria. The criteria of effectiveness in the descriptive analysis are as follows:

Table 2: Criteria of Effectiveness

\begin{tabular}{ll}
\hline Formula & Criteria \\
\hline $\mathrm{Mi}+1,5 \mathrm{Sdi} \leq \mathrm{M} \leq \mathrm{Mi}+3 \mathrm{Sdi}$ & Effective \\
$\mathrm{Mi}+0,5 \mathrm{Sdi} \leq \mathrm{M}<\mathrm{Mi}+1,5 \mathrm{Sdi}$ & Effective adequate \\
$\mathrm{Mi}-1,5 \mathrm{Sdi} \leq \mathrm{M}<\mathrm{Mi}+0,5 \mathrm{Sdi}$ & Ineffective \\
$\mathrm{Mi}-3 \mathrm{Sdi} \leq \mathrm{M}<\mathrm{Mi}-1,5 \mathrm{Sdi}$ & Very Ineffective \\
\hline
\end{tabular}

Source: Hanum (2013:96)

\section{Research Results and Discussion}

Figure 1 presents the pretest result of group A and figure 2 presents the pretest of group B. Comparing the pretest result between two groups that the maximum score of the group a is greater than group B. However, each means is same as 60 . That means these two groups is almost similar.

\section{Figure 1: Pretest Result of Group}

Pretest Result of Interactive Media Learning



Figure 2: Pretest Result of Group

Pretest Result of Characterized Memes Media Learning

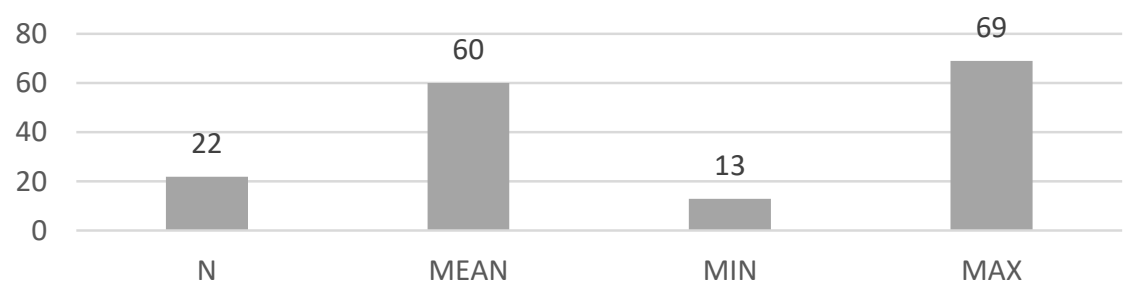

\section{Classical Learning Completeness}

Result of Paired Sample T-Test: To figure out whether there is a difference in learning achievement of healthy lifestyle material on physical education subject of students previously and subsequently taught using interactive media or using characterized memes, the study applied paired sample t-test. Table 3 presents the result of paired sample t-test. 
Table 3: Analysis Result of Score between Pretest and Posttest

\begin{tabular}{lccc}
\hline & N & Mean & Sig.(2-tailed) ${ }^{*}$ \\
\hline Interactive Media & & & \\
Pretest & 24 & 60 & 0.00 \\
Posttest & 24 & 77 & \\
Characterized Memes Media & & & \\
Pretest & 22 & 60 & 0.00 \\
Posttest & 22 & 77 & \\
\hline
\end{tabular}

*: $95 \%$ confidence interval

The mean score between pretest and posttest was significantly increased from 60 to 77, there was a 17 point increase. Based on the paired sample t-test, $p=.00$ is less than $\alpha$ level, .05 . This presents that score at pretest was significantly different with the score at posttest. Therefore, it concluded that the students' learning outcomes were significantly increased.

The result of Independent Sample T-Test: To determined whether there is a difference in learning achievement between interactive media and characterized memes media, this study applied independent sample t-test. Table 4 presents the result of the independent sample t-test.

Table 4: Analysis Result of Posttest Score between Interactive Media and Characterized Memes Media

\begin{tabular}{lccc}
\hline & N & Mean & Sig.(2-tailed) \\
\hline Interactive Media & & & \\
$\begin{array}{l}\text { Posttest } \\
\text { Characterized Memes Media }\end{array}$ & 24 & 77 & 0.972 \\
Posttest & 22 & 77 & \\
\hline
\end{tabular}

*: $95 \%$ confidence interval

Based on table 4, the mean posttest score between interactive media and characterized memes media was the same as 77. According to the paired sample t-test, $\mathrm{p}=.972$ is greater than $\alpha$ level, .05 . This presents that posttest score of interactive media was significantly no different with posttest score which taught characterized memes media. Therefore, it concluded that there is no difference between student learning achievement was taught by using interactive media and characterized memes media

Classical Completeness: Table 5 below provides the proportion of the classical completeness of student learning achievement by taught using interactive media and characterized memes media. Based on the posttest score, the percentage of classical completeness of student who was taught by using interactive learning media reached to 89.12 percent, while using characterize memes learning media reach 60.41 that not reached the classical completeness.

Table 5: Analysis Result of Posttest Score between Interactive Media and Characterized Memes Media

\begin{tabular}{lccc}
\hline & Mean & Number & \% \\
\hline Interactive Media & 77 & 21 & 89.12 \\
$\begin{array}{l}\text { Posttest } \\
\text { Characterized Memes Media }\end{array}$ & 77 & 13 & 60.41 \\
Posttest & 77 & & \\
\hline
\end{tabular}

Achievement of Teaching Effectiveness in Learning Process: Observation to teaching activity in the interactive media group conducted for four meetings. On the observation of the highest average teaching activity amounted to 4.40 which included in the category effective. From the teaching activity observation, among the five aspects, there were two aspects such as visual and motor activity that had the highest average compared with other aspects. Meanwhile, the observation towards teaching activity in the characterized memes media group conducted during four meetings. On the observation of the highest average teaching activity amounted to 4.68 which included in the category effective. From the teaching activity observation, 
among the five aspects, there was one aspect such as a visual activity that had the highest average compared with other aspects.

Achievement of Student Learning Effectiveness in Learning Process: Based on the student activity sheet, on the observation of interactive media group the average learning activity amounted to 3.65 which included into the effective adequate. From beginning to the end of class, the students actively engaged. There was an active interaction between teacher and students as well as among students. By interactive media, the students were enabled to ask the teacher freely, and assisted in mastering the material. From the played video, the students consider and maintain personal health habits. However, in the characterized memes media group, based on the student activity sheet, the average learning activity amounted to 3.1 which included into the effective adequate. In this group, the media applied power point slides. Most of the slides displayed some memes related to funny words and innuendo of unhealthy living habits. Initially, the students were enthusiastic and actively involved, yet gradually the students' concentration degrades slowly by doing the activities of self-joking.

Discussion: It caused less attention of the students to the material presented by the teacher. Frequently, the students joked with their classmates because the memes in slides perceived familiar on social media. In addition, in terms of appropriate student learning activity in the classroom using interactive media reached 90.12 percent, while in memes characterized media class character merely 66.65 percent. Therefore, from the three aspects explained above, comparing to enhancing students' learning achievement, teaching and learning activity, it concluded that learning by using interactive media was more effective than using characterized memes media. Learning material healthy lifestyle on physical education by using interactive media conducted in this study improved the effectiveness of learning since the interactive media more dominate the activity of students, train teachers in creativity to teach theoretical topics in the classroom. Accordance with that by seeing and simultaneously listening, the person receiving the lesson, illumination or counselling is able to be more quickly understand the meaning of instructor. Through an audio-visual media, students felt enthusiastic (Miftakh \& Samsi, 2015) and motivated to learn and master the lessons (Firdaus, 2014).

Even more, Firdaus (2014) stated that audio-visual media was better than print media. Media represent what the teacher is unable to explain through words or sentences (Ainina, 2014). Abstract topics are concretized by the presence of media. Thus, students will more easily digest the lessons rather than without media help. One of the teaching strategies conducted by teachers to present the material in the classroom more interesting and accessible is such as by using instructional media (Jaliusril et al., 2012). On the other hand, though characterized meme media improved the student learning achievement, yet it was into the less effective category. Based on the results of interviews and observations, students enjoyed delivered understanding with serious activities. In characterized meme media, at the beginning of the lesson students seem enthusiastic to learn but in line with the learning time there is a decrease of concentration by doing the activities of self-joking and less attention to the material presented by the teacher. Repeatedly, students joke with a classmate because the slides they perceived familiar on social media. The impression that students capture is a funny and often parodied image. The memes were not able to generate characterized memes media as an introduction to the delivery of appropriate material because the media more emphasised on the expression of the displayed image.

Nugraha et al. (2015) argued that memes were one of the phenomenon of delivering a message in a new form by combining verbal language with nonverbal communication (expression). The content of characterized memes media emphasised the photographs that caused students' attention only limited to the peculiarities and differences between the slides with one slide to another. As stated by Wadipalapa (2015) that memes feature combinations of photographic images, slides and texts, and are intended to respond to an issue that is being discussed in social discourse. Differences between these two media revealed that interactive media provided more advantages than characterized memes media. This is based on the result of observation value both to the students and to the teacher that the value of interactive media obtained the average score of 4.04 (responses on the effective category) and meme media get the average score of 2.90 (responses effective sufficient category). Based on the students 'opinion, it is known that interactive media has an advantage in the form of more students' value in making the class situation more active. While the media meme character caused many students considered the memes were funny that causes less conducive learning situation. 


\section{Conclusion}

Based on the results and discussion, it concluded that both interactive media and characterized memes media improved the students learning achievements. However, compared to the effectiveness of each media, the interactive media was more effective than characterized media. Therefore, it is important that the physics teacher could implement the interactive media particularly for theoretical topics such as personal health, healthy lifestyle and environmental health. Teachers with a different subject, this study might provide a new sight how to apply media in their learning. Additionally, schools could consider this study as a reference to develop other related media in the classroom teaching.

\section{References}

Ainina, I. A. (2014). Pemanfaatan media audio visual sebagai sumber pembelajran sejarah. Indonesian journal of history education, 3(1), 2252-6641.

Arsyad. \& Azhar. (2011). Media Pembelajaran. Jakarta: Raja Grafindo Persada.

Conrad, P. (2017). Taking the Pulse of the Online Classroom: Data-based Student Engagement. International Journal for Educational Media and Technology, 17.

D, D. (2010). Media Pembelajaran peranannya sangat penting dalam mencapai tujuan pembelajran. Yogyakarta: Pustaka Pelajar.

Dantes, N., Dharsana, K. \& Sutrisna, G. N. (2017). Penerapan Model Pembelajaran Kooperatif Type TGT dengan media kartu kata untuk meningkatkan motivasi belajar dan kemampuan membaca. International Journal of Elementary Education, 1(1), 19.

Daryanto, D. (2010). Media Pembelajaran peranannya sangat penting dalam mencapai tujuan pembelajran. Yogyakarta: Pustaka Pelajar.

Dawkins, R. (1967). The selfies gene. New York: New York University.

Depdiknas. (2008). Kamus Besar Bahasa Indonesia. Jakarta: Balai Pustaka.

Education of Ministry. (2016). Curriculum planning \& development division. Singapore: Primary-SecondaryPre University.

Firdaus. (2014). Efektivitas penggunaan media audio-visual dalam pembelajaran sains. Jurnal Spektra.

Garrison, D. R., Anderson, T. \& Archer, W. (2000). Critical inquiry in a text-based environment: Computer conferencing in higher education. The Internet and Higher.

Hanum, N. S. (2013). Keefektifan E-Learning Sebagai Media Pembelajaran (Studi Evaluasi Model Pembelajaran E-Learning Smk Telkom Sandhy Putra Purwokerto) . Jurnal Pendidikan Vokasi.

J, K, S. (2014). The development of children's understanding of map and models a prospective cognition . Journal of cognitive education and phycology Volume 13(2), 19.

Jaliusril, Asyhar, R. \& Harjono, H. S. (2012). Pengembangan media audio-visual pembelajaran lari jarak pendek untuk SMP. Jurnal Tekno-Pegagogi, 2, 1.

Kariman, T. M. (2014). Pemanfaatan Web Blog sebagai media pembelajran untuk meningkatkan hasil belajar bahasa inggris. Jurnal Teknology Pendidikan.

Kobel, S., Keszztyus, K. D., Eekelenz, N., Drenowatz, C. \& Steinacker, J. (2010). Correlates of habitual physical activity and organized Sport in German Primary School Children. Humberg.

Mannaf, I., Khanna, G. l. \& Chandra, P. D. (2010). Effect of training an antonometric, physiological and biochemical variables of elite field Hockey Players. International Journal Of Sports science and engineering, 236.

Marens. \& Rainer. (2004). Successful Coaching 3 rd Edition . Champaign: Human Kinetics.

Mendoza, G. A., Jung, I. \& Kobayashi, S. (2017). A Review of Empirical Studies on MOOC Adoption: Applying the Unified Theory of Acceptance and Use of Technology. International Journal for Educational Media and Technology, 22.

Miftakh, F. \& Samsi, Y. S. (2015). Penggunaan media audio visual dalam meningkatkan kemampuan menyimak mahasiswa. Jurnal ilmiah solusi, 2(5), 2355-1119.

Mosston, M. \& Ashworth, S. (2010). Teaching Physical Education F i r s t 0 n l i n e E d i t i o n. San Diego: New York City Association of Physical Education Teachers.

Mulyasa, E. (2003). Management berbasis sekolah. Bandung: Remaja Rosdakarya.

Northcote, M. (2008, November). 
Nugraha, A., Sudrajat, R. H. \& Putri, B. P. (2015). Fenomena meme di media sosial: studi etnografi virtal posting meme pada pengguna media sosial instagram. Jurnal Sosioteknologi, 14(3), 238.

Olivares, P. R., Cassios- Balanos, M. A., Gomes Campos, R. a., Almonacid-Fiero, A. a. \& Rubio, G. (2015). Influences of parents and physical education teachers in adolescent physical activity. International Journal of clinical and health psychology, 15.

Paek, S. \& Fulford, C. (2017). Learning Instructional Design in a Flipped Classroom: A Comparison of Online and Face-to-Face Formats. International Journal for Educational Media and Technology, 32.

Park, K. M. \& Park, H. (2015). Effects of self-esteem improvement program on self-esteem and peer attachment in elementary school children with observed problematic behaviors. Journal Asian nursing research $\mathrm{xxx}, 7$.

Putro, E. W. (2013). Teknik penyususunan instrumen penelitian. Yogyakarta: Pustaka Pelajar.

Roux, P. W., Suzuki, K., Matsuba, R. \& Goda, Y. (2018). Developing Cultural Intelligence (CQ): Designs for Blended Learning. International Journal for Educational Media and Technology, 27.

Seaman, J. (2013). Social Media For Teaching and Learning. Boston: Pearson Learning Solutions and Babson Survey Research Group.

Sheehan, J. K. (2014). The development of children's understanding of map and models a prospective cognition. Journal of cognitive education and phycology Volume, 13(2), 19.

Sinambella. (2006). keefektivan model pembelajaran berdasarkan masalah (problem based Instrction) dalam pembelajaran matematika untuk pokok bahasan sistem linear dan kuadrat dikelas X SMA Negeri 2 Rantau Selatan Sumut. Surabaya: PPS Unesa Press.

Smith, L. A., Gardner, B. b. C. D. A. \& Hamer, M. (2015). Preventive Medicine. Journal of Public Health, 129.

Sianturi, M. \& Lin , H. H. (2017). Effects of Student's Grade to Teacher's Teaching: a Case Study in an Indigenous Classroom. Journal of Education and Vocational Research, 7(4), 6-11.

Sianturi, M., Chiang, C. L. \& Hurit, A. A. (2018). Impact of a Place-Based Education Curriculum on Indigenous Teacher and Students. International Journal of Instruction, 11(1), 311-328.

Sumarsono, A. (2017). Implementasi Model Pembelajaran Atletik Melalui Permainan Berbasis Alam. Magistra, 71.

Sumarsono, A. (2018). The four-net game to improve students'psychomotor skill. Advances in Social Science, Education and Humanities Research, volume 226 1st International Conference on Social Sciences.

Sulistyo, N. H. (2013). Keefektifan e learning sebagai media pembelajran (studi evaluasi model pembelajaran eleraning SMK Telkom Sandhy Putra Purwokerto). Jurnal Pendidikan Vokasi, 3, 1.

Sun, H. (2013). Journal of sport and Health Science, 2, 144.

Takabayashi, T. (2017). Expectations of learning media for self-directed learning: Learners' perceptions of media choice. International Journal for Educational Media and Technology, 11(1), 59-67, 63.

Vaughan, N. D., Cleveland-Innes. \& Garrison, D. R. (2013). Teaching in blended learning environments: creating and sustaining communities of inquiry. Edmonton: AU Press.

Wadipalapa, R. P. (2015). Meme culture \& komedi-satire politik:kontestasi pemilihan presiden dalam media baru. Jurnal Komunikasi, 12(1), 2.

Yu, W. (2017). STEMS2, Social Presence and Sense of Place in a Hybrid Distance Program. International Journal for Educational Media and Technology, 47. 